\title{
The IAD-SES-ILT model in assessing the governance of a river basin
}

DOI: $10.46932 /$ sfjdv2n2-084

Received in: March 1st, 2021

Accepted in: May 30th, 2021

\section{Antonio Paulo da Silva}

$\mathrm{PhD}$ student in Ecology and Environmental Health by the Fernando Pessoa University

Controllership and Ombudsman of the State of Ceará

Address: 100 Francisco Xerez Street, Guararapes, Fortaleza - CE, Brazil

E-mail: 37792@ufp.edu.pt

\section{Maria João Simas Guerreiro}

$\mathrm{PhD}, \mathrm{MSc}$

Associated Professor at the Fernando Pessoa University

Fernando Pessoa University, Faculty of Science and Technology

Address: 349 Praça 9 de Abril, Silva Braga, Porto, Portugal

E-mail: mariajoao@ufp.edu.pt

\section{Samíria Maria Oliveira da Silva]} $\mathrm{PhD}, \mathrm{MSc}$

Adjunct Professor in the Hydraulic and Environmental Engineering Department, Federal University of Ceará

Address: Professor Armando Farias Street, Block 713, 1st Floor, Centro de Tecnologia, Pici, Fortaleza CE, Brazil

E-mail: samiriamaria@ufc.br

\section{Carlos Henrique da Silva Sousa}

$\mathrm{PhD}$ student in Information Science by the Fernando Pessoa University

Federal Institute of Education, Science and Technology of Ceará

Address: 2081 Treze de Maio Avenue, Benfica, Fortaleza - CE, Brazil

E-mail: 39266@ufp.edu.pt

\begin{abstract}
This paper presents the IAD-SES-ILT heuristic model built from the combination of the Institutional Analyzes Development (IAD) framework of Elinor Ostrom and the Institutional Legal Theory (ILT). Using the grammatical syntax for the examination of institutional statements, proposed by Crawford and Ostrom, the structure of the Action Situation levels (Constitutional, Collective and Operational Choice) that make up the governance of the Hydrographic Basin of the Metropolitan Region of Fortaleza was analyzed . It was possible to show that the legal view introduced to the IAD-SES by ILT added new values to the institutional approach, allowing an assessment of governance regarding the respect for the principles indicated by the OECD as necessary for good governance of water resources.
\end{abstract}

Keywords: Hydrographic Basin, Governance, Principles, IAD-SES-ILT. 


\section{INTRODUCTION}

The water crisis is largely due to a governance crisis and the efficient management of this common resource involves overcoming social and political challenges (OECD, 2015). Recognizing these issues, in its 2020 Water and Climate Change report, UNESCO stated that in order to have good governance, it is necessary to respect the included human rights, the effective, the responsiveness and the accountability; openness and transparency; participation in the performance of the main governance functions related to political and institutional measures; planning and coordination; as well as regulation and licensing (UNESCO, 2020).

This work presents a heuristic model based on the combination of the Institutional Analyzes Development (IAD) framework by Elinor Ostrom and the Institutional Legal Theory (ILT), while analyzing the institutional environment that constitutes the governance of the Watersheds of the Metropolitan Region of Fortaleza, to show how much the institutional arrangement contemplates the principles indicated by the Organization for Economic Cooperation and Development (OECD) indicated as necessary for good governance.

In its latest version, the IAD framework by Elinor Ostrom, presents a link to the theory of SocioEcological Systems (SES) incorporating new levels of analysis and variables, namely: the governance system, the resource system, the resource unit and a detailing of variables that allow a better understanding of the actors involved in the system under study. Also included in the composition of the IAD-SES institutional framework, the Action Situation - understood as situations in which individuals interact with each other affecting the results -, emphasizing the socio-cultural, institutional and biophysical context in which decisions are made (Ostrom, 2011).

Despite the IAD-SES structure already allowing an analysis of the governance of a socioecological system, by adding the institutional legal view through the Institutional Legal Theory (ILT), to reach the IAD-SES-ILT, it becomes possible the evaluation through a simple analysis of the institutional declarations issued through the available documentation.

For the introduction of the institutional legal view to the IAD-SES, it is assumed that participants in action situations proceed, or wish to proceed, in accordance with the law, both with regard to their actions and the results intended with resources, which means the practice of acts in accordance with formal rules. This "legal posture" has two biases: first, that both the actions and the intended results must comply with the formal rules and, second, that the actors have the possibility to make changes to the formal rules, affecting the "space "Legal-institutional in which the actions and results are practiced, such as when signing a contract or issuing a license. 
Analytically, there are three levels of action situations for the IAD-SES-ILT that involve changing formal rules, namely: the level at which a power assignment rule is made - creating a legal capacity or "space" legal-institutional; the level at which this rule is being applied by the practice of a legal act - the use of legal capacity to alter legal freedoms; and the level at which the scope of lawful factual actions is changed - use of legal freedom in a legal-institutional "space" in which actions are taken. Following the structure of the IAD-SES, these levels are associated, respectively, with the constitutional, collective and operational choice levels.

A central issue is that only legal acts carried out on the basis of a legal rule that confers power, established at a deeper level of action, can actually cause legal effects. This occurs through the introduction, amendment or revocation of legal rules. By using this understanding at the different levels of action situations, it becomes possible to distinguish the interactions at these levels in terms of understanding the rules of conduct or power that structure these interactions.

In general, the management of the Hydrographic Basins of the Metropolitan Region of Fortaleza (BHRM) is responsible for 16 sub-basins distributed in 31 municipalities located in the northeast of the State of Ceará-Brazil (art. 1 of Decree $n^{\circ} 33.073$ / 2019). The region is home to the largest water consuming center in the State of Ceará-Brazil where water availability has been insufficient to meet all economic and human consumption activities, requiring the importation of water from other hydrographic basins. The increased demand for the consumption of water resources has required interaction with other Socio-ecological Systems and, increasingly, the recognition of the need to create management mechanisms that provide for the fair distribution of resources and induce a change in behavior that recognizes the need for sustainable use.

\section{THE HEURISTIC MODEL IAD-SES-ILT}

The IAD-SES arose from an intense fieldwork to prove, empirically, that the results of collective action do not necessarily imply the "tragedy" announced by the traditional theory of common goods proposed by Hardin (1968), with the methodological and disciplinary exchange given relevant contributions to the growing understanding of socio-ecological systems (Amy, Ostrom and Janssen, 2011). Based on this understanding, the Institutional Legal Theory (ILT) was evaluated for compatibility with the relations established by the rules dealt with in the IAD-SES.

The proposal to join ILT with the conceptual and methodological map proposed by Elinor Ostrom does not mean the inclusion of yet another structure or set of variables to those already indicated in the IAD-SES, but a re-reading of the rules that make up the institutional arrangements. In this sense, and considering that the rules are the point of contact between the theory and the conceptual map, we 
proceeded to analyze all the material collected for a classification of the rules conveyed in these documents. This process allowed the stratification of several rules at the action situation levels.

Depending on the object or perspective of an investigation, institutional analysis can be done by evaluating the rules at three levels of action situation, namely: the level of constitutional situation, the level of collective choice situation and the level of operational situation .

In the constitutional situation, there are the rules that make, change and enclose formal rules that define a process, who participates and how participation takes place in the situation of collective choice; in the situation of collective choice, there are the processes of formation of institutions and political decisions in line with the rules established at the level of the constitutional situation. At this level, legitimate areas of action are defined to be carried out at the operational level; and finally, at the level of operational situation there are decision-making, the day-to-day actions developed by the actors in line with the rules established at the levels of collective and constitutional choice.

An important issue to be assessed concerns the effectiveness of the norms, that is, whether the formal rules they convey find factual support and legitimacy in the social environment. Add to this the adaptability of governance to unexpected events that demand from the actors a behavior hitherto devoid of specific rules. For the assessment of these issues, in addition to the instruments provided by the IADSES, a good tool may be the use of Institutional Legal Theory, which is now presented in a succinct way.

Institutionalism was developed with the initial concern of constitutional, administrative law and answers to questions such as: "How to integrate people into collective structures and projects and ensure interpersonal relationships and mutual interdependence?" and "Where does the legitimacy of political authorities come from?" (Zamora et al., 2015). The theory makes a counterpoint to the extreme normativism according to which the law is understood, exclusively, through the norms.

For MacCormick (2007), the law corresponds to an institutional normative order seen as a set of social expectations to which numerous actions practiced by the participants can be attributed. The formation of a queue, as in a supermarket, is used by the author to illustrate the phenomenon.

Without the existence of a specific rule, the actions taken by the participants in a queue occur out of respect for the fact that they know what is right to do intuitively, based on an expectation or a more or less similar understanding about what a queue is and when whether to form it. It is possible that when trying to explicitly articulate the training rules, people give slightly different instructions about the exact meaning of the queue, but a similar understanding in this regard makes it possible to successfully coordinate the action. The formation of the queue is born from the interpretative convergence of some ideas that give rise to a community of ideas to what the author calls a convention (MacCormick, 1998). 
MacCormick (2007) states that the normative order of law cannot be based merely on social conventions, since the disregard for the system's prescriptions can bring more disastrous consequences for the process of social integration than simply a queue not reaching its purpose . For the author, it is necessary to introduce a greater degree of certainty in understanding the content and effectiveness of legal rules, which can be achieved with rule and authority. These are the two mechanisms that allow us to move from an informal normative order, such as that of the supermarket queue, to a formal normative order, such as that of law.

Unlike legal positivism, institutionalism starts from an abstract set of values to which members of social practices adhere when engaging in articulations about what is right to do. In addition, the set of expectations for the action is shaped by values in a specific social, political and economic context.

The concept of institution goes beyond the norms that define an entity such as a court, a parliament or a government, it also includes those that designate what jurists call an institute, such as family, affiliation, contract, inheritance, among others. countless others that can be classified in an abstract plan (type institution) or concrete (item institution) (Zamora et al., 2015). The type institution (ideal type, category) constitutes the institute in the abstract or in existence on the legal plane, such as a contract in general, while the item institutions (specific case) are on the social plane in accordance with universal norms.

Institutions are defined by rules of three types, namely: constitutive rules, consecutive rules and terminative rules. The constitutive rules define the outline of the institutions, that is, they determine the conditions within which the recognition and identification of the type institution can be affirmed and, as it defines the outlines, the existence of each of the item institutions.

The consecutive rules determine, after creating the outline of an institution, the set of relationships that follow, such as rights, obligations, immunities, powers, faculties, prerogatives, subjections, sanctions, among others. These rules condition social action in space and time, defining the operation of institutions.

Finally, the terminative rules that define the conditions by which an abstract (type) or concrete (item) institution is concluded or extinguished, in addition to providing for the transitional regime to be applied when consummating extinction.

The addition of ILT to the IAD-SES allows to focus on rules that describe behaviors and the identification of normative aspects that allow, or not, the construction of harmonious institutional arrangements and aligned with the sustainable use of common resources Lammers and Heldeweg (2019).

At the various levels of action situation, actors can, acting within a given legal space, produce acts (rules in use) in accordance with a formal rule (rule in form) or exercise the ability to produce changes in rules by modifying the space itself (for example, by signing a contract or by issuing a license). From the 
point of view of the IAD-SES, the production of new standards results from interactions within a "legislative" Action Situation, with the intention of impacting the rules in use of another higher-level action situation.

Although the rules of power that determine the normative capacity space applicable to participants in a given action situation have not been discussed by Ostrom, they are a major issue in institutionalist theory. Thus, for institutionalists, only legal acts performed on the basis of a legal norm that confers power - established at a lower level of action - can actually cause legal effects through the introduction, alteration or repeal of legal rules. Analytically, three levels of action situations are involved in the normative modification:

1. the level at which a power assignment rule is made - creating a normative capacity (Ostrom's constitutional level);

2. the level at which this rule (following 1.) is being applied through the practice of a legal act use of the normative capacity to alter legal freedoms (Ostrom's level of collective choice);

3. the level at which the scope of lawful factual actions is changed (by 2.) - use of legal freedom (Ostrom's operational level).

At IAD-SES-ILT, the analysis of action situations at different levels is seen based on rules of conduct or power that structure interactions. Table 1 below shows the structure of the action situation levels (SA), the rules in use (ReU), the rules of conduct (RdC); rules of power (RdP) and rules in form $(\mathrm{ReF})$.

Table 1: Levels as action situations where acts are performed based on rules for empowerment.

\begin{tabular}{|c|c|c|}
\hline Action Situation Level (SA) & Interaction (I) & $\begin{array}{l}\text { Rules that structure } \\
\text { the Action Situation } \\
\text { (SA) }\end{array}$ \\
\hline Operational situation (SO) & $\begin{array}{l}\text { Performance of factual activities, for } \\
\text { example: } \\
\text { - establish a company } \\
\text { - running a neighborhood cooperative } \\
\uparrow \text { RdCs made by the SEC for use in SO } \uparrow\end{array}$ & $\begin{array}{l}\text { ReUs following } \\
\text { "deeper origin" } \\
\text { (CCS) RdCs } \\
\text { involving } \\
\text { prohibitions, } \\
\text { commands, } \\
\text { permissions and } \\
\text { waivers (and } \\
\text { freedoms) }\end{array}$ \\
\hline $\begin{array}{l}\text { Collective Choice Situation } \\
\text { (SEC) }\end{array}$ & $\begin{array}{l}\text { Enter, change, close RdCs, for example: } \\
\text { - contracting between the participants of the } \\
\text { operating system (first part regulation) } \\
\text { - permission / subsidy by non-operating } \\
\text { system participants (second part) } \\
\text { - co-regulating formal or substantive } \\
\text { standards for OS interactions }\end{array}$ & $\begin{array}{l}\text { ReUs following RdPs } \\
\text { made by SC (with } \\
\text { positions and } \\
\text { conditions) on: } \\
\text { - how to make / } \\
\text { change RdCs in the } \\
\text { SEC, for OS-ReUs }\end{array}$ \\
\hline & $\uparrow$ RdPs made by SC for use in the SEC $\uparrow$ & $\begin{array}{l}\text { ReUs following RdPs } \\
\text { (with positions and }\end{array}$ \\
\hline
\end{tabular}


Results of the Constitutional Situation (CS)

Constitutional situations (SC)
Make, change, end ReF, for example:

- (RdP for SEC) Civil Code; Electricity Act;

- (RdP to SEC) as a meta-regulation for

private rules on products / services to make / change

$\mathrm{RdPs}$ in SC to ReUs

in SEC

Source: Lammers and Heldeweg (2019, p.4).

For Lammers and Heldeweg (2019), against the background of the IAD rules, the requirement of prescriptive legal consistency to allow effective and legitimate collective action requires; a) the consistency of legal institutions to ensure consistency between the rules to be made for legal institutions that operate within a particular action situation (at a particular level); b) the consistency of the action situation to ensure that properly formed legal institutions (consistent in accordance with.) allow a consistent structure for a specific action situation, given the desired results (at that specific level); and c) level consistency to ensure that such an action situation, duly established, (consistent in accordance with b.) is consistently aligned with exits at lower levels or entrances at higher levels of action situations.

In order to map the relationships at each action situation level and between these levels, institutional statements were examined, identified in the documentary analysis, based on the grammatical syntax proposed by Crawford and Ostrom, (1995).

\section{RESEARCH METHOD}

The assessment of the action situation levels for the disclosure of the prediction of principles that point to good governance in institutional arrangements, the research followed the guidelines for coding institutional declarations in the terms presented by Basurto et al. (2009). Crawford and Ostrom (1995) state that there are three types of institutional statements that can be observed, namely: the Rule, the Standard and the Strategy.

For the evaluation of these statements, Crawford and Ostrom provide a grammatical syntax indicated by the acronym "ADICO" that represents, respectively, attribute (A), deontic (D), aim (I), condition $(\mathrm{C})$, and or else $(\mathrm{O})$. The three types of institutional statements are created from different combinations of the ADICO syntax: The strategies include only the attribute, aim and the condition (AIC); the standards include the attribute, deontic, aim and condition (ADIC); and the rules consist of all the syntax, an attribute, deontic, aim, condition, and or else (ADICO).

The attribute (A) is understood as the individual or the organization to which the institutional declaration applies; deontic (D) is a prescriptive operator of what can be allowed, mandatory or prohibited; aim (I) describes the objectives or actions to which the deontic operator refers; condition (C) represents operators when and where the objective is permitted, required or prohibited; the or else $(\mathrm{O})$ operator is the punitive action applied when a rule is not enforced. 
A first activity developed was the survey of all documentation used as a means of manifesting institutional declarations such as laws, decrees, resolutions, technical documents and minutes of meetings. From the survey, a total of 60 documents of content considered relevant to the research were arrived at, as shown in Table 2.

Table 2: Profile of the analyzed documents.

\begin{tabular}{cccc}
\hline Type of document & National & Local & Total \\
\hline Laws & $\mathbf{6}$ & $\mathbf{4}$ & $\mathbf{1 0}$ \\
Decrees & $\mathbf{1}$ & $\mathbf{4}$ & $\mathbf{5}$ \\
Resolutions & $\mathbf{3}$ & $\mathbf{9}$ & $\mathbf{1 2}$ \\
Minutes of Meetings & -- & $\mathbf{2 3}$ & $\mathbf{2 3}$ \\
Technical Documents & -- & $\mathbf{1 0}$ & $\mathbf{1 0}$ \\
Total & $\mathbf{1 0}$ & $\mathbf{5 0}$ & $\mathbf{6 0}$ \\
\hline
\end{tabular}

Source: Prepared by the authors.

Then, in possession of the raised documentation, the guidelines for the codification of institutional declarations were applied, as indicated by Basurto et al. (2009):

a. All definitions, titles, preambles and headings were identified and disregarded for coding purposes;

b. The sections and subsections of each document were identified as initial observation units;

c. All initial sections or subsection units of step "b." Were subdivided who had several sentences in sentence-based observation units;

d. The observation units were coded following the syntax "ADICO", relating the text in each unit to the attribute (A), deontic (D), aim (I), condition (C), and or else (O) coding;

e. All rule-type observation units were coded. In this regard, to avoid incompatibility with Institutional Legal Theory, the work did not consider the types of statements of the type norms and strategies;

f. Finally, we proceeded to subdivide all observation units based on sentences that had more than one rule.

The last stage of the work was to assess, based on the institutional arrangements evidenced by the institutional statements, the existence of statements that demonstrate the consistency of prescription for the levels of action (constitutional, collective and operational choice) and respect for the stated principles OECD as necessary for good governance of water resources.

\section{RESULT AND DISCUSSIONS}

The results are presented from the assessment of the consistency of the legal institution, the situation of action and the levels of situation of action, correlating them with the principles indicated by the OECD. 
From the survey of institutional statements, contained in the analyzed documentation, it was possible to evidence the profile of observation units related to BHRMF (attribute). The figures were consolidated in tables 3 and 4 : 
Table 3: Profile of observation units associated with BHRMF and OECD principles.

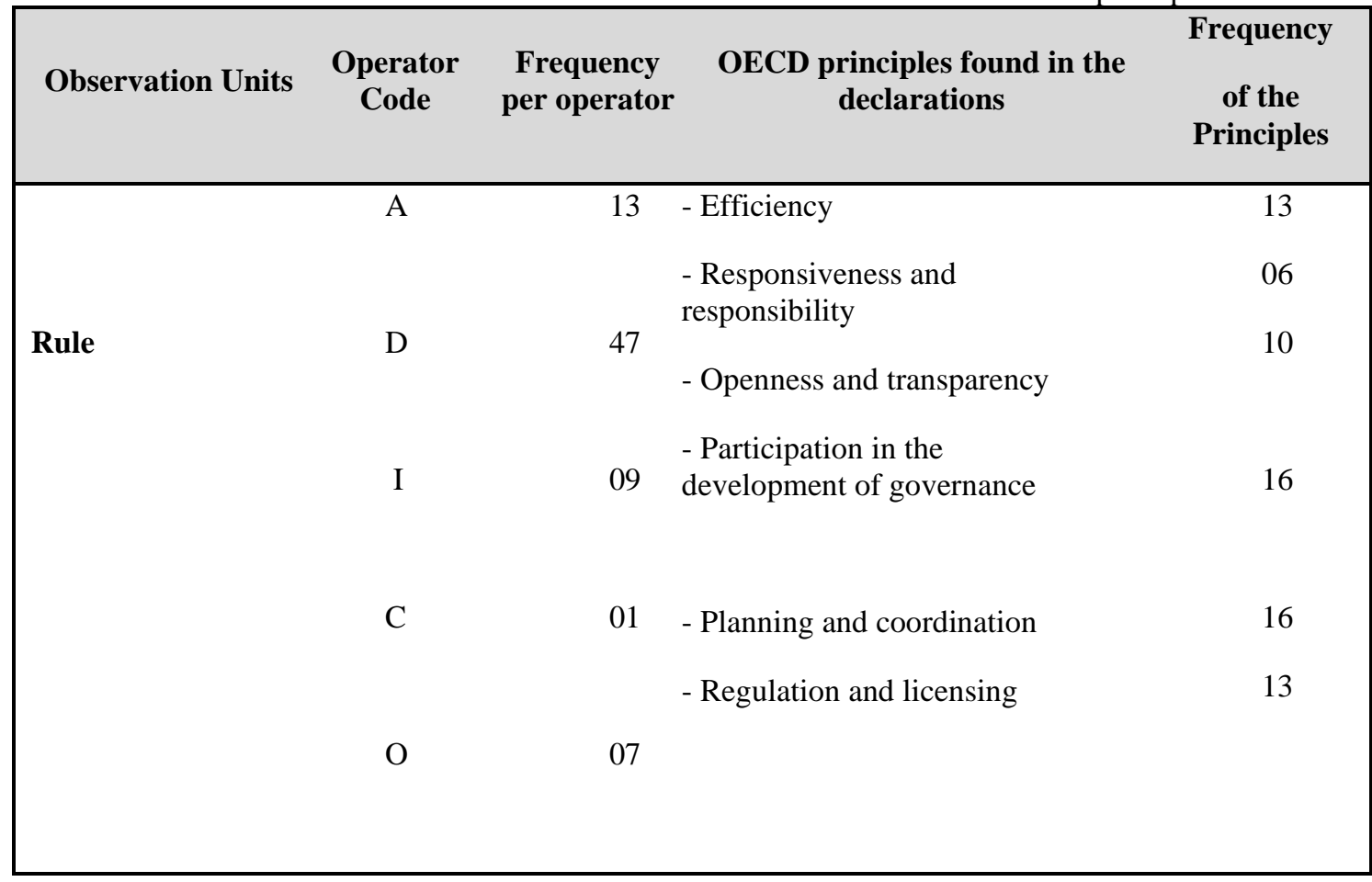

Source: Prepared by the authors.

The documentary analysis showed that of a total of 77 institutional declarations identified, $61 \%$ were deontic, that is, they bring rules that oblige, prohibit or allow the performance of the actors. An example of these types of declarations can be seen in $\$ 2$ of art. 52 of the State Law n ${ }^{\circ} 14.844$ / 2010 that instituted the State Water Resources Policy. The aforementioned provision states: "All water interference must be granted in accordance with this Law, its regulations and federal legislation". Following, we had 13 (thirteen) statements that refer to legal institutions; 09 (nine) with statements regarding the objectives to be achieved; 07 (seven) referred to some sanction and only 01 (one) statement tried to show a conditional rule.

Regarding the rules that enunciate statements in line with the principles indicated by the OECD, it was possible to verify that the documentary analysis evidenced institutional declarations covering all the principles, with a preponderance for participation in the development of governance and in planning and coordination, both presenting 16 ( sixteen) statements. Then came efficiency and regulation and licensing, both with 13 (thirteen) statements, followed by openness and transparency and responsiveness and responsibility with 10 (ten) and 09 (nine) statements, respectively.

Table 4 shows the distribution of rules between the levels of the action situation. At the deepest (constitutional) level, documentary analysis showed a greater number of statements, 29 (twenty nine), followed by the intermediate level (collective choice), with 26 (twenty six), and the operational level with 15 (fifteen). 
Table 4: Profile of observation units at the Action Situation levels.

\begin{tabular}{|ccc|}
\hline Observation Units & Action Situation Level & Frequency \\
\hline Rule & Constitutional & 29 \\
& Collective Choice & 26 \\
& Operational & 15 \\
\hline
\end{tabular}

Source: Prepared by the authors.

Table 5 presents some examples of rules collected in the statements emanating from the analyzed documentation, distributed along the levels of action situation, which evidence the governance structure at BHRMF.

Table 5: Structuring the levels of action situations.

\begin{tabular}{|c|c|c|}
\hline $\begin{array}{l}\text { Action Situation Level } \\
\text { (SA) }\end{array}$ & Interaction (I) & $\begin{array}{l}\text { Rules that structure the } \\
\text { Action Situation (SA) }\end{array}$ \\
\hline $\begin{array}{l}\text { Operational situation } \\
\text { (SO) }\end{array}$ & $\begin{array}{l}\text { Performance of factual activities, for example: } \\
\text { - Resolution of the Metropolitan Region Basin } \\
\text { Committee: "Creates the Working Group for } \\
\text { the Revision of the Internal Rules of the CBH } \\
\text { RMF and creation of the Monitoring } \\
\text { Committee for the Allocation of the waters of } \\
\text { the Jaguaribe Valley - RMF" (Minutes of the } \\
51 \text { st Ordinary Meeting. }\end{array}$ & $\begin{array}{l}\text { ReUs following } \\
\text { "deeper origin" (CCS) } \\
\text { RdCs involving } \\
\text { prohibitions, } \\
\text { commands, permissions } \\
\text { and waivers (and } \\
\text { freedoms) }\end{array}$ \\
\hline & $\uparrow$ RdCs made by the SEC for use in SO $\uparrow$ & \\
\hline \multicolumn{3}{|l|}{ SEC Results } \\
\hline $\begin{array}{l}\text { Collective Choice } \\
\text { Situation (SEC) }\end{array}$ & $\begin{array}{l}\text { Enter, change, close RdCs, for example: } \\
\text { - Resolution of the State Water Resources } \\
\text { Council (CONERH): "... prohibition on the } \\
\text { issuance of new grants, as well as renewal, for } \\
\text { the purpose of surface irrigation in the basin of } \\
\text { the lower Jaguaribe ..." ( } 89 \text { th Minutes of the } \\
\text { Regular Meeting of CONERH) }\end{array}$ & $\begin{array}{l}\text { ReUs following RdPs } \\
\text { made by SC (with } \\
\text { positions and } \\
\text { conditions) on: } \\
\text { - how to make / change } \\
\text { RdCs in the SEC, for } \\
\text { OS-ReUs }\end{array}$ \\
\hline
\end{tabular}




\section{$\uparrow$ RdPs made by SC for use in the SEC $\uparrow$}

Results of the Constitutional Situation (CS)

Constitutional situations (SC)
Make, change, end ReF, for example:

- (RdP for SEC) Examples: Art.41. of Law 14.844 / 2012: "The Ceará Water Resources Council - CONERH, coordinating, supervising, collective and normative decision-making body of the Integrated Water Resources Management System - SIGERH, linked to the SRH Water Resources Secretariat, will the exercise of the following competences: ".
ReUs following RdPs (with positions and conditions) on how to make / change RdPs in $\mathrm{SC}$ to ReUs in SEC

Source: Adapted from Lammers and Heldeweg (2019, p.4).

The institutional statements evidenced in the analyzed documentation, pointed towards the consistency of the institutions, the action situations and the situation levels. In addition, it was possible to identify in the declarations elements indicative of respect for the principles enunciated by the OECD as necessary for good governance.

\section{CONCLUSION}

The results found allow us to conclude that the IAD-SES-ILT model shows promise as it allows an evaluation based on the simple analysis of documents produced by the management of the hydrographic basin. From the analysis of the institutional statements issued by the actors, it is possible to obtain evidence of the quality of governance, without the need for long and tiring interview processes.

An important issue to be highlighted concerns the institutionalist perspective brought by the Institutional Legal Theory (ILT). This theory proved to be not only compatible with the IAD-SES, but capable of adding value, as it allows a look at the rules that structure the interactions taking into account their connection with the facts that occur in the real world. It is not enough to just consider an institutional statement, issued in the interaction between actors, for the assessment of governance, it is necessary to consider that this statement is coherently associated with the reality of the facts that occur in the day-today management.

It must be taken into account that the purpose of this work, before presenting an in-depth analysis of the governance of BHRMF, was to indicate, to some extent, the viability of the IAD-SES-ILT model. In this sense, several adjustments were made that mitigated the achievement of results such as the number of documents analyzed, the distribution of these documents by entities that operate within the scope of 
BHRMF. In this sense, the need for a greater number of documents that allow obtaining a greater number of declarations at the operational level where the actions are practiced by the actors must be recognized.

The assessment of institutional declarations using the "ADICO" syntax proved to be very promising considering that all manifestations of the actors occur at the linguistic level and subsuming themselves to the indicated operators. In this regard, the statements considered in these works were only those classified as rules. With this measure, it was avoided the confrontation of conceptual legal questions about the legal norms besides bringing a focus to the rules that are considered the core of Elinor's IADSES framework. 


\section{REFERENCES}

Amy R., Ostrom, E. \& Janssen, M. A. (2011). Trabalho em parceria: ação coletiva, bens comuns $e$ múltiplos métodos. São Paulo, Editora Senac São Paulo.

Basurto, X., Kingsley, G., McQueen, K., Smith, M., \& Weible, CM (2010). A Systematic Approach to Institutional Analysis: Applying Crawford and Ostrom's Grammar. Political Research Quarterly, 63 (3), 523-537.

Crawford, S. \& Ostrom, E. (1995). A grammar of institutions. American Political Science Review, 89 (3), pp. 582-600. https://www.cambridge.org/core/journals/american-political-sciencereview/article/abs/grammar-of-institutions/7D37CD3BC5ED2D9FD57D2EE292958F47> (Accessed in February $\left.25^{\text {th }}, 2021\right)$.

Diário Oficial do Estado do Ceará (2019). Decreto $\mathrm{n}^{\circ} 33.073$, de 21 de maio de 2019. http://www.cbhrmf.com.br/institucional/regimento/ (Accessed in February 25 ${ }^{\text {th }}, 2021$ ).

Diário Oficial do Estado do Ceará (2010). Lei n 14.844 de 31 de dezembro de 2010. Dispõe sobre a Política Estadual de Recursos Hídricos e institui o Sistema Integrado de Gestão de Recursos HídricosSIGERH. https://belt.al.ce.gov.br/index.php/legislacao-do-ceara/organizacao-tematica/desenv-regionalrecursos-hidricos-minas-e-pesca/item/379-lei-n-14-844-de-28-12-10-do-30-12-10 (Accessed in February $\left.25^{\text {th }}, 2021\right)$.

Hardin, G. (1968). The Tragedy of the Commons, Science, 162, 1243-1248.

Heldeweg, M. A. \& Lammers, I. (2019). An empirico-legal analytical and design model for local microgrids: applying the 'ILTIAD' model, combining the IAD-framework with institutional legal theory. International Journal of the Commons, 13 (1), pp. 479-506. http://www.thecommonsjournal.org (Accessed in February 25 ${ }^{\text {th }}, 2021$ ).

Maccormick, N. (2007). Institutions of law. Nova York, Oxford University Press, 2007.

OCDE (2015). Princípios da OCDE para a Governança da Água. https://search.oecd.org/cfe/regionaldevelopment/OECD-Principles-Water-portuguese.pdf (Accessed in March $\left.3^{\text {rd }}, 2021\right)$.

Ostrom, E. (2011). Thinking About the Future: A Social-Ecological Systems Approach to Sustainability, Resilience 2011 - Second International Science and Policy Conference, March 11-16, Arizona, EUA.

UNESCO (2020). Relatório Mundial das Nações Unidas sobre Desenvolvimento dos Recursos Hídricos 2020: água mudança climática, executivo. https://unesdoc.unesco.org/ark:/48223/pf0000372882_por (Accessed in February 20 ${ }^{\text {th }}, 2021$ ).

Zamora, J. L. F., Vaquero, Á. N. (2015). Enciclopedia de Filosofía y teoría del derecho, volumen uno, México, UNAM, Instituto de Investigaciones Jurídicas. 